\title{
APELA Gene
}

National Cancer Institute

\section{Source}

National Cancer Institute. APELA Gene. NCI Thesaurus. Code C137984.

This gene plays a role in endoderm differentiation, heart development and angiogenesis. 